\title{
Improving the Quality of Technical Vocational Education and Training (TVET) For
} Sustainable Growth and Development of Nigeria

\author{
Clever Omovigho Igberaharha \\ Department of Business Education, Delta State University, Abraka, Nigeria. \\ Email:ighoclevo@yahoo.com Tel: +2348033485476
}

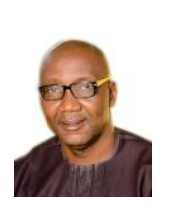

\begin{abstract}
This study was undertaken towards improving the quality of Technical Vocational Education and Training (TVET) at the university level for the sustainable growth and development of Nigeria. Two research questions guided the study, and two null hypotheses were tested. The design of the study was a descriptive survey with a population of 116 respondents. These TVET lecturers were drawn from five universities in the South-South region of Nigeria. The entire population was used for the study. To collect pertinent data for the study, the researcher developed a 20-item questionnaire. Face and content validity of the questionnaire was determined by three experts. In order to establish the reliability of the instrument, Cronbach Alpha was used, which gave a reliability coefficient of 0.86 . Mean was used to analyze the data relating to the research questions while Pearson product moment correlation coefficient was used to test the null hypotheses. The study found that the quality of TVET at the university level can be improved, for the sustainable growth and development of Nigeria, through professional manpower and the provision of efficient facilities and equipment. Also, the study findings indicated a significant relationship between the quality improvement of TVET and the sustainable growth and development of Nigeria. It was recommended that TVET providers, policymakers, stakeholders, and governments in Nigeria should ensure 'Education for Sustainable Development' is fully integrated into the TVET program to ease the national development of the Nigerian economy.
\end{abstract}

Keywords: Improving, Quality, TVET, Sustainable growth, Development, Nigeria.

Citation | Clever Omovigho Igberaharha (2021). Improving the Quality of Technical Vocational Education and Training (TVET) For Sustainable Growth and Development of Nigeria. Journal of Education and e-Learning Research, 8(1): 109-115.

History:

Received: 14 August 2020

Recived: 14 Angust 2020

Acrised: 23 Decer 2020

Accepted: 27 January 2021

Published: 10 February 2021

Licensed: This work is licensed under a Creative Commons

Attribution 3.0 License $($ cc)

Publisher:Asian Online Journal Publishing Group
Funding: This study received no specific financial support

Competing Interests: The author declares that there is no conflict of interest the publication of this paper.

Transparency: The author confirms that the manuscript is an honest, accurate, and transparent account of the study was reported; that no vital features of the study have been omitted; and that any discrepancies from the study as planned have been explained.

Ethical: This study follows all ethical practices during writing.

\section{Contents}

1. Introduction ................. 110

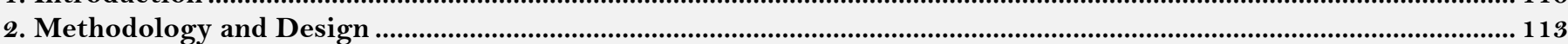

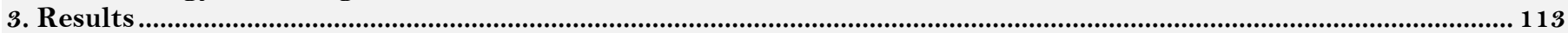

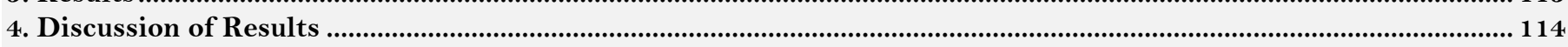

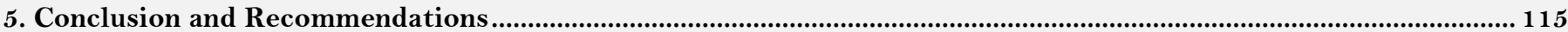

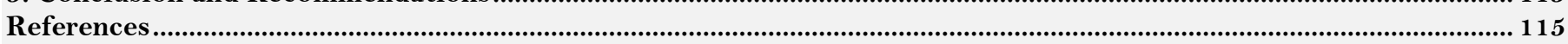




\section{Contribution of this paper to the literature}

The findings of this study have positive implications for a TVET program in relation to the sustainable development of Nigeria. Therefore, the study has contributed to the existing body of knowledge as highlighted herein: The knowledge gained from the findings reveals that the quality of TVET at the university level can be improved through professional manpower training for the sustainable growth and development of Nigeria. This implies that quality professional manpower development in TVET will improve its quality and, therefore, culminate in the sustainable growth and development of Nigeria. The findings of this study would tremendously benefit educational agencies and authorities in decision making, knowing that improved provision of efficient equipment and facilities for TVET will enhance the sustainable growth and development of Nigeria to a significant extent.

\section{Introduction}

Education plays a significant role in the foundations of the economic, social, cultural, and political development of any nation. Globally, education is considered essential and accorded priority in national development plans because it is the most crucial tool of change. Furthermore, any critical change in perspective, either socially or intellectually, is usually occasioned by an educational revolution. Thus, the accomplishment of this role depends on an education that has global relevance. This urgency was reflected in the aim of the UN goal of "Education for Sustainable Development," 2005-2014, launched by UNESCO on 1 March 2005. This initiative strove to "integrate the values ingrained in sustainable development into all areas of learning to encourage changes in behavior that allow for a more sustainable and just society for all(UNESCO, 2005)."

Various global and local initiatives in education, like the integration of Education for Sustainable Development (ESD) in the teaching programs and curricula at various levels of education, show an increasing engagement and commitment towards an ESD goal. The UNESCO-UNEVOC International Centre in Bonn has been committed to this goal and is playing vital roles at the Technical Vocational Education and Training level (TVET). TVET is globally recognized as a critical driving force for the technological development and socio-economic growth of nations, and TVET is progressively considered to be the prime base of all national developments(Afeti, 2010).

TVET, according to (Mar, 2011), is defined as "an encompassing term referring to all areas of the educational process that, in addition to general education, involves:

- The study of technologies and other related sciences.

- The attainment of practical skills, knowledge, attitudes, and understanding relating to occupations in different sectors of social and economic life.

- A means of training for occupational engagements and for efficient participation in the labor world.

- An area of lifelong learning and training for effective citizenship.

- A tool for enhancing environmentally appropriate sustainable development.

- A method of improving poverty reduction."

According to the UNESCO International Centre for TVET (UNESCO-UNEVOC, 2019),"Technical and Vocational Education and Training is involved with the acquisition of skills, competencies, and knowledge for the world of work. TVET is an incredibly diverse sub-sector of education and training. It comprises formal, nonformal, and informal learning. It develops skills and knowledge from basic to advanced levels and shapes people's attitudes. It takes place across a wide range of institutional settings, including schools, public and private vocational institutes, tertiary education institutions, community projects, at home, and in the workplace in both the formal and informal economies." TVET harnesses and improves skills for innovation, working, lifelong learning, and living, as well as for a contribution to human, socio-economic, environmental, and technological aspects of development.

Similarly, TVET is structured as a set of approaches to learning, both to prepare students for the world-ofwork, for well-being later in adult life. Additionally, TVET can contribute significantly to skills development and also to human resource strategies and policies that are targeted to serve the different needs of the national and international labor markets. In particular, as the experience of numerous countries shows, successful TVET can serve as an effective function in skills development, both traditionally and in new trades and industries. It can also build societal, group, and individual re-adjustment after catastrophe and conflicts and strengthens resilience and social capital.

Moreover, "TVET is a way to prevent social exclusion and its consequences. It can contribute to reducing international inequities through debt restructuring and financial transfers, boost national economic growth, contribute to institutional development, thereby enabling a favorable environment for growth, help to provide for basic needs and strengthen the social sector and social security, develop human capital, empower populations, and encourage social inclusion, participation, and rights-based approaches (including gender, ethnic, and age based inclusion(UNESCO-UNEVOC, 2019)." It can further contribute to building livelihoods by reducing intergenerational inequities (environment) and contributing to preparing populations for disaster management and rehabilitation (reducing vulnerability to shocks at various levels), as well as achieving peacemaking and reconciliation. "TVET has played a significant role in responding to the needs of skilled workers and technical cadres of countries in the thrusts of modernization and industrialization. Technical Cooperation programs from the 1950 s to the 1980 s and in post-independence Africa of the 1960 s supported the formation of training institutions, curricula, methodologies, and equipment reflecting the traditions and the technologies of donors' TVET systems. Donors paid more attention to building or enhancing the countries' capacities to supply skills than to the labor markets that were to make use of such skills."

In most nations of the world, there is no priority placed on the coordination between ministries and authorities to assist programs handled by diverse international agencies. "Training systems became fragmented, and training providers often used different European models to provide technical solutions for patterns of industrialization referred to in Europe. The rise of education for all in the 1990s left TVET as a residual priority for technical cooperation. Funding for public training provision declined in favor of emphases towards basic education. TVET institutions were forced to recover costs, often by prioritizing training and production over learning and even 
competing with local producers, with a competitive advantage of subsidized facilities and non-wage labor(UNESCO-UNEVOC, 2019)."

Within this same period, the private sector increased its provision of manpower training. Funding systems, like levies and vouchers, were put on the same level as public sector training provision. The private sector preponderantly provided training on aspects such as accounting and commerce, communication technologies and information management, and foreign languages and tended to keep away from the high capital investment costs of industrial training. "They were generally located in major cities and proved less motivated to include vulnerable groups or persons with special needs. Such categories were often considered to represent higher costs, carrying greater risks of non-graduation. Governments continued to engage in TVET because of concerns about the quality (staff, curriculum, and material development) and quantity of private-for-profit provision." But today, private training providers have developed to a superior level with enhanced methodologies.

In most countries considered to be developing nations, TVET occupies a significant national space for its goal to train the upcoming generation to approach the world of work, first, with attendant skills, and second, to address the unavoidable demands of the current developmental trends and provide the relevant nation with a competent workforce trained in accordance with industry expectations. Thus, the vocational and technical education association specifically targets developing and improving occupational capacity (consisting of occupational, methodical, social, and industrial competencies) of its participants. Developing these competencies engenders the desired performance and enhances each trainee's suitability for effective employment.

One of the critical indices in the training and development of occupational capacity in TVET is the availability and adequacy of competent trainers or teachers. In TVET, teachers are highly significant in establishing the level of excellence of TVET results. In this study, TVET teachers are highlighted, with the focus on vocational education and training in formal education at the post-secondary level. As already submitted by various formal international organizations like the World Bank and UNESCO-UNEVOC, it is reported that "TVET teachers in developing countries frequently fail to meet the demands of the world of work. The teachers' poor pedagogical skills significantly decrease the process of know-how transfer to the students, with the result that education in its entirety loses its effectiveness. This is caused by student learning being dominated by passive learning processes offering little or no support in the development of much-needed professional competence. In addition, the teachers' own industrial skills are revealed to be a critical weakness(UNESCO-UNEVOC, 2019).”

This situation is inherent in many developing countries leading to an aspect of the university-based model and/or the framework of TVET trainers' development being insignificant. From the very beginning, the training system does not demand that students acquire holistic industrial experience, neither before admission into the training program nor following graduation from the course. In the training process, practical sessions are often not given adequate attention. The training program is usually condensed into a sandwich of theories, most of which are obsolete as a result of a shortage of research, innovations, and lack of professional development programs for TVET educators. Obviously, the skill and knowledge shortfall of TVET educators concerning updates in the world of work is quite disturbing. The critical question that such deficit begs to be answered is, of course, "How can TVET participants be updated if the capacity of their teachers is out of date?"

The outcome of education in terms of quality is proportionate to the quality of its teachers. If a nation is committed to providing top notch vocational education and training programs, it, therefore, becomes crucial that it engages teachers with the prerequisite experience and competencies to deliver. The nexus concerning the relevance of practical and vocational training must improve to the extent that it can bring about a new framework in the qualifications of the teacher (Chakroun, 2019).

Over the years, parents and other stakeholders in education have indicated that quality teachers are significant factors needed for the enhancement of student performance, and several studies carried out since 1990 have completely proved this assertion. For example, (OECD, 2009)"found that students, taught by teachers at the top of the effectiveness scale attain as much as an additional year of growth in student learning compared with being taught by teachers near the bottom of the scale. This means a gain of 1.5 years of academic growth rather than 0.5 years of growth in a single year."

Another vital development is the emphasis placed on workplace training to improve and upgrade personal skills through further learning as a direct response to skills inadequacies and mismatches. An outlook that favors enterprise-based learning over learning in institutions has garnered support. However, in most countries, "Corporate investment in human resource development was reduced when economies contracted and entered into crises. Consequently, firms, especially smaller firms, seldom had available funds and proved reluctant to invest in training employees, for fear that trained workers would leave." If the situation is left unattended, sustainable national development and economic growth will be stifled.

Age (2005) listed some goals which sustainable national development is expected to achieve, including "increase in capital income and employment, improving human welfare, meeting basic needs, and safeguarding the environment. Considering the course of later generations, realizing equity between the rich and poor, participation on a broad basis in development and decision making is critical."

Onah (2011) defined sustainable development as "development that not only generates economic growth but distributes its benefits equitably, that regenerates the environment rather than destroying it, and that empowers people rather than marginalizing them; a development that gives priority to the poor, enhancing their choices and opportunities and providing for their participation in decisions that affect their lives. A sustainable economy, therefore, is a continuous development of an economy with national regenerative impact."

The most captivating thing about sustainable economic development is that it places cognizance on the current situations of individuals while at the same time does not compromise people who will follow. Thus, the notion of sustainable development continues to be a modern index for measuring positive growth. A sustainable economy entails meeting the demands of the current situation without necessarily neglecting the capacity of younger generations to address their own demands.

In another definition, Munasinghe (2004) states, "sustainable national development is a process of improving the range of opportunities that will enable individual humans and communities to achieve their aspirations and full 
potential over a sustained period of time while maintaining the resilience of economic, social and environmental systems."

Sustainable development implies the all-round and stable development of individuals and society. This agrees with the submission made by China, Lilly, and Igbemi (2017) that sustainable development is all about enhancing people's lives. In the perspective of Hansa (2014),"sustainable development involves the carrying capacity of natural systems with economic, political, and social challenges facing society. Sustainable development entails a holistic approach to promoting the quality of living through the effective allocation of available natural resources. On the basis of business enterprise, sustainable development refers to applying business practices and strategies that meet the goals of the enterprise and its stakeholders and improving the human and natural resources that will be required in the future."

The goal of sustainable development is to attain social, economic, and environmental equity. In its template for sustainable development, the United Nations Development Programme (2015) lined-up various sustainable development targets. The sustainable development target, also known in the UNDP schedule as "transforming our world," is a set of targets to transform the world by 2030. Considering the foregoing, however, the researcher embarked on this study towards improving the quality of Technical Vocational Education Training (TVET) at the university level for the sustainable growth and development of Nigeria.

These sustainable development goals include:

1. "End extreme poverty, including hunger.

2. Promote economic growth and decent jobs within the planetary boundaries.

3. Achieve gender equality, social inclusion, and human rights.

4. Achieve health and well-being at all ages.

5. Improve agricultural systems and raise rural prosperity.

6. Empower inclusive, productive, and resilient cities.

7. Curb human-induced climate change and ensure sustainable energy provision.

8. Secure biodiversity and ensure good management of water, oceans, forests, and natural resources.

9. Transform governance and technologies for sustainable development(Nwokike, Ezeabii, \& Jim, 2018).”

A sustainable economy is multidisciplinary, interdisciplinary, and cross-sectoral. It brings together specialists and professionals from the different fields of education, physical and environmental sciences, economics, political science, appropriate technology, arts, human rights, and others. In this paper, a sustainable economy is conceived as referring to an appreciable or advancing nation that meets the needs and aspirations of individuals educationally, socially, economically, and technologically, and which is targeted towards improving the living standard of the people. In other words, succeeding at a sustainable economy entails equipping graduates with vital skills for selfemployment through functional education so they can contribute maximally to the economic development of the nation.

In addressing the issue of improving the quality of TVET for the sustainable growth and development of Nigeria, some questions come to mind, including, "What is the current state of TVET? What is the quality of TVET in Nigeria? How can TVET be better positioned for sustainable development?" These questions are the gaps which this paper intends to address.

\subsection{Statement of the problem}

The quality of education available in Nigerian institutions of higher learning has been weakened over the years. "In recent years, the educational system has passed through tremendous odds, which has placed a grip of insecurity and uncertainty about the relevance of educational instruction to current market realities(Okumagbe, 2007).” An aspect of the many challenges affecting institutions of learning is the steadily increasing mismatch between the needs of the society (reflected through the needs of industries) and the skills obtainable in the school system occasioned by poor quality education.

Out of the segment of education that could provide remedies to the aforementioned challenges, education for sustainable development through TVET is possible. Therefore, this study was undertaken towards improving the quality of TVET for the sustainable growth and development of Nigeria.

\subsection{Purpose of the study}

The study was undertaken towards improving the quality of TVET for the sustainable growth and development of Nigeria. This purpose was further broken down into the following specific objectives:

1. To improve the quality of TVET at the university level through professional manpower for the sustainable growth and development of Nigeria.

2. To improve the quality of TVET at the university level through the efficient provision of equipment and facilities for the sustainable growth and development of Nigeria.

\subsection{Research questions}

The following research questions guided the study:

1. To what extent can the quality of TVET at the university level be improved through professional manpower for the sustainable growth and development of Nigeria?

2. To what extent can the quality of TVET at the university level be improved through the efficient provision of equipment and facilities for the sustainable growth and development of Nigeria?

\subsection{Hypotheses}

The following null hypotheses were tested at a 0.05 level of significance:

Ho: $\quad$ There is no significant relationship between improving the quality of TVET at the university level through professional manpower and the sustainable growth and development of Nigeria.

Ho:: $\quad$ There is no significant relationship between improving the quality of TVET at the university level through the efficient provision of equipment and facilities and the sustainable growth and development of Nigeria. 


\section{Methodology and Design}

The descriptive survey design was used for this study. The population of the study consisted of 116 respondents who were TVET lecturers in universities in the South-South region of Nigeria (Edo, Delta, Bayelsa, and Rivers States). Since the population was a manageable size, the entire population was used for the study. The population is shown in Table 1 below.

Table-1. Population of the study.

\begin{tabular}{|c|c|c|}
\hline $\mathbf{S} / \mathbf{N}$ & Universities & No. of respondents \\
\hline 1 & University of Benin, Benin City & 25 \\
\hline 2 & Ambrose Alli University, Ekpoma & 16 \\
\hline 3 & Delta State University, Abraka & 29 \\
\hline 4 & Niger Delta University, Bayelsa & 21 \\
\hline \multirow[t]{2}{*}{5} & Rivers State University of Science and Technology & 25 \\
\hline & Total & 116 \\
\hline
\end{tabular}

\subsection{Research instrument}

The instrument for data collection was a structured questionnaire developed by the researcher from insight gained from the literature review. The instrument was named "Improving the Quality of Technical Vocational Education Training (TVET) for Sustainable Growth and Development Assessment Questionnaire.” The questionnaire contained 20 items designed to generate data from the respondents in a five-point Likert format as follows: "Very High Extent" (5points); "High Extent" (4points); "Moderate Extent" (3points); "Low extent" (2points); and "Very Low Extent" (1point).

\subsection{Validity and reliability of the instrument}

The design and content validity of the instrument was determined by three experts. The initial copy of the questionnaire was given to three TVET lecturers for scrutiny in terms of appropriateness, sufficiency, and clarity. Their suggestions were considered in drafting the final copy of the questionnaire. To establish the reliability of the instrument, Cronbach Alpha was used to test the pilot study data generated from a small group that was similar to the study respondents, and the test yielded a coefficient index of 0.86 , which was indicative of the reliability of the questionnaire.

\subsection{Method of data analysis}

Data obtained from the administration of the questionnaire were analyzed with mean in order to answer the research questions, while a Pearson Product Moment Correlation (PPMC) Coefficient was used to test the null hypotheses at a 0.05 level of significance. In calculating the mean for the various items, the response category in the questionnaire was rated in scales as follows:

\section{Response category}

High Extent (HE)

Low Extent (LE)

Very Low extent (VLE)
Very High Extent (VHE)

Moderate Extent (ME)

$\begin{array}{ll}\text { Point } & \text { Boundary limit } \\ 5 & 4.50-5.00 \\ 4 & 3.50-4.49 \\ 3 & 2.50-3.49 \\ 2 & 1.50-2.49 \\ 1 & 1.00-1.49\end{array}$

The boundary limits above informed the researcher on the decision rule for the research questions. For the null hypotheses, when the calculated value was greater than the table value at 0.05 level of significance, the null hypothesis was rejected, while when the calculated value was less than the table value at 0.05 level of significance, the null hypothesis was accepted.

\section{Results}

Research question one: To what extent can the quality of Technical Vocational Education Training (TVET) at the university level be improved through professional manpower for the sustainable growth and development of Nigeria?

Table-2.Mean responses to research question one

\begin{tabular}{|c|c|c|c|c|}
\hline $\mathbf{S} / \mathbf{N}$ & Item statements & $\mathbf{N}$ & Mean & Remark \\
\hline 1 & $\begin{array}{l}\text { Continuous training for TVET lecturers will improve the quality of } \\
\text { TVET for sustainable growth and development. }\end{array}$ & 116 & 4.20 & High Extent \\
\hline 2 & $\begin{array}{l}\text { Proper implementation of training grants to enhance lecturers' skills } \\
\text { can improve the quality of TVET for sustainable growth and } \\
\text { development. }\end{array}$ & 116 & 3.66 & High Extent \\
\hline 3 & $\begin{array}{l}\text { Exposure of TVET lecturers to global educational trends will improve } \\
\text { the quality of TVET for sustainable global growth and development. }\end{array}$ & 116 & 3.70 & High Extent \\
\hline 4 & $\begin{array}{l}\text { TVET lecturers gaining modern ICT skills will enhance their } \\
\text { professional development by improving the quality of TVET for } \\
\text { sustainable growth and development. }\end{array}$ & 116 & 3.64 & High Extent \\
\hline 5 & $\begin{array}{l}\text { TVET can be restructured with its lecturers employing the best } \\
\text { pedagogical practices for sustainable growth and development. }\end{array}$ & 116 & 3.58 & High Extent \\
\hline \multirow[t]{2}{*}{6} & $\begin{array}{l}\text { Practical professional development for TVET lecturers will improve } \\
\text { the quality of TVET for sustainable growth and development. }\end{array}$ & 116 & 3.72 & High Extent \\
\hline & Weighted Mean & & 3.75 & High Extent \\
\hline
\end{tabular}


Table 2 shows that all items regarding the extent to which the quality of TVET at the university level can be improved through professional manpower for the sustainable growth and development of Nigeria had a high value. Therefore, since the weighted mean is 3.75 , which is within the boundary limit of High Extent, this indicates that the quality of TVET at the university level can be improved through professional manpower for the sustainable growth and development of Nigeria.

Research question two: To what extent can the quality of TVET at the university level be improved through the efficient provision of equipment and facilities for the sustainable growth and development of Nigeria?

\begin{tabular}{|c|c|c|c|c|}
\hline$\overline{S / N}$ & Item statements & $\mathbf{N}$ & Mean & Remark \\
\hline 1 & $\begin{array}{l}\text { Availability of e-libraries will improve the quality of TVET } \\
\text { for sustainable growth and development. }\end{array}$ & 116 & 4.12 & High Extent \\
\hline 2 & $\begin{array}{l}\text { Regular power supply in tertiary institutions can improve the } \\
\text { quality of TVET for sustainable growth and development. }\end{array}$ & 116 & 4.16 & High Extent \\
\hline 3 & $\begin{array}{l}\text { Well-equipped laboratories will improve the quality of TVET } \\
\text { for sustainable growth and development globally. }\end{array}$ & 116 & 4.52 & High Extent \\
\hline 4 & $\begin{array}{l}\text { Modern workshops for skills acquisition can improve the } \\
\text { quality of TVET for sustainable growth and development. }\end{array}$ & 116 & 3.83 & High Extent \\
\hline 5 & $\begin{array}{l}\text { Conducive classrooms will improve the quality of TVET for } \\
\text { sustainable growth and development. }\end{array}$ & 116 & 3.60 & High Extent \\
\hline 6 & $\begin{array}{l}\text { Availability of ICT facilities will improve the quality of } \\
\text { TVET for sustainable growth and development. }\end{array}$ & 116 & 3.58 & High Extent \\
\hline 7 & $\begin{array}{l}\text { Availability of modern office gadgets will improve the quality } \\
\text { of TVET for sustainable growth and development. }\end{array}$ & 116 & 4.16 & High Extent \\
\hline \multirow[t]{2}{*}{8} & $\begin{array}{l}\text { Steady and efficient internet facilities will improve the quality } \\
\text { of TVET for sustainable growth and development. }\end{array}$ & 116 & 4.56 & High Extent \\
\hline & Weighted Mean & & 4.07 & High Extent \\
\hline
\end{tabular}

Table 3 shows that all items regarding the extent to which the quality of TVET at the university level can be improved through the efficient provision of equipment and facilities for the sustainable growth and development of Nigeria had a high value. Therefore, since the weighted mean is 4.07 , which is within the boundary limit of high extent, this indicates that the quality of TVET at the university level can be improved through the efficient provision of equipment and facilities for the sustainable growth and development of Nigeria.

\subsection{Test of null hypotheses}

Ho: There is no significant relationship between improving the quality of TVET at the university level through professional manpower and the sustainable growth and development of Nigeria.

Table-4.Pearson Product Moment Correlation Co-efficient (r) Computation for TVET Lecturers on the Variables of Quality of TVET through Professional Manpower and Sustainable Growth and Development.

\begin{tabular}{l|c|c|c|c|c|c|c}
\hline Variables & N & Mean & r-cal & r-crit & Df & Decision \\
\hline Professional manpower & 116 & 4.03 & 0.72 & 0.2319 & 114 & Significant P>0.05 \\
\cline { 1 - 1 } $\begin{array}{l}\text { Sustainable growth and } \\
\text { development }\end{array}$ & 116 & 4.00 & & & & \\
\hline
\end{tabular}

The data in Table 4 shows that there is a positive correlation between professional manpower and sustainable development in the quality of TVET $(\mathrm{r}=0.72)$. This means that the null hypothesis is not accepted, and the alternative is upheld. Therefore, there is a significant relationship between improving the quality of TVET at the university level through professional manpower and the sustainable growth and development of Nigeria.

$\mathrm{Ho}_{2}$ :There is no significant relationship between improving the quality of TVET at the university level through the efficient provision of equipment and facilities and the sustainable growth and development of Nigeria

Table-5.Pearson Product Moment Correlation Co-efficient (r) Computation for TVET Lecturers on the Variables of Quality of TVET through Efficient Provision of Equipment and Facilities and Sustainable Growth and Development.

\begin{tabular}{l|c|c|c|c|c|c}
\hline Variables & N & Mean & r-cal & r-crit & Df & Decision \\
\cline { 1 - 3 } Equipment and facilities & 116 & 4.03 & 0.81 & 0.2319 & 114 & Significant P>0.05 \\
\cline { 1 - 3 } Sustainable growth and development & 116 & 4.00 & & & & \\
\hline
\end{tabular}

The data in Table 5 shows that there is a positive correlation between the efficient provision of equipment and facilities and sustainable growth and development in the quality of TVET $(r=0.81)$. This means the null hypothesis is not accepted, and the alternative is upheld. Therefore, there is a significant relationship between improving the quality of TVET at the university level through the efficient provision of equipment and facilities and the sustainable growth and development of Nigeria.

\section{Discussion of Results}

The study was undertaken to work towards improving the quality of TVET at the university level for the sustainable growth and development of Nigeria. The study revealed that the quality of TVET at the university level could be significantly improved through professional manpower for the sustainable growth and development of Nigeria. Moreover, there is a significant relationship between improving the quality of TVET at the university level through professional manpower and the sustainable growth and development of Nigeria. In supporting the findings, Ivancevich (2014) deduced that professional manpower is a process that attempts to provide an employee with information, skills, and an understanding of a career. Professional manpower is designed to help TVET 
lecturers make positive contributions in the form of good performance, which can, in turn, improve the quality of TVET for sustainable growth and development.

The study further showed that the quality of TVET at the university level could be significantly improved through the efficient provision of equipment and facilities for the sustainable growth and development of Nigeria. Moreover, there is a strong relationship between improving the quality of TVET at the university level through the efficient provision of equipment and facilities and the sustainable growth and development of Nigeria. These findings collaborate the views of Onifade and Onifade (2011), who opined that the various institutions that are charged with the responsibility to provide professional training for teachers, to achieve a nation's goals and, by extrapolation, the national goals are lacking the relevant and necessary facilities and equipment needed for effective training. This underscores the fact that if the necessary facilities and equipment are made available for TVET, its quality will be improved to occasion the nation's sustainable growth and development.

\section{Conclusion and Recommendations}

TVET is broadly acknowledged as a crucial driving wheel for the sustainable growth and development of any nation. Once the quality of TVET, especially at the university level, is improved through professional development and the efficient provision of equipment and facilities, sustainable growth and development become inevitable. This position is predicated upon the findings of the study. In light of the findings, the following recommendations were made:

1. The government at all levels, stakeholders in TVET, TVET providers, and policymakers in Nigeria should ensure Education for Sustainable Development is fully integrated into the TVET program for ease of the national development of the Nigerian economy.

2. The present curriculum of TVET at the university level needs reinventing, retouching, modifying, adjusting, and adapting to bring about sustainable growth and development.

3. To address the problems of globalization, demographic and technological changes, and sustainable development, and to overcome skill misalignments and shortfalls, TVET should commission a program that will integrate elements that anticipate and create skills among TVET providers for future needs with the development of new curricula linked to the tertiary sector and new technologies.

\section{References}

Afeti, G. (2010). Technical and vocational education and training for industrialization.

Age, E. (2005). Objectives of teaching education in Nigeria. London: British Council.

Chakroun, B. (2019). The challenges of technical vocational education and training (TVET) at a global level. Retrieved from: http://www.cepal.org.

China, M. A., Lilly, G., \& Igbemi, M. J. (2017). Sustainable development: A case for female-headed households in the Diger Delta region of Nigeria. International Journal of Scientific Research in Education, 10(2), 145-155.

Hansa, M. (2014). Features of sustainable development. Canada: Ohawa Policy Research.

Ivancevich, J. M. (2014). Human resource management (12th ed.). St Louis: McGraw-Hill Co.

Mar, V. (2011). Introducing UNESCO's technical vocational education and training (TVET) definition and strategy: A Publication of UNESCO on TVET Definition. Retrieved on the 2nd of March 2020 from https://www.unesco.com.

Munasinghe, S. (2004). Effective instructions through dynamic displine. Ohio: Charles E. Merill.

Nwokike, F. O., Ezeabii, I. C., \& Jim, E. U. (2018). Business education: An indispensable tool for achieving sustainable development in the South-East States of Nigeria. British Journal of Education, 6(1), 19-27.

OECD. (2009). Recommendation on principles and good practices for financial education. Retrieved from: http://www.oecd.org/finance/financial-education/35108560.pdf.

Okumagbe, S. E. (2007). Building a qualitative education in Nigeria: Prospects and challenges. Paper presented at the Being a Paper Presented at the 2nd Annual National Conference, Organized by Association of Nigerian Academics at FCE (T) Asaba, between 2nd -6th April, 2007.

Onah, F. O. (2011). Improving human development index in Nigeria: The task before local governments. In T. Onyishi (Ed.) Key issues in local government and development: A Nigerian perspective (pp. 147-160). Enugu: Praise House Publishers.

Onifade, G. O., \& Onifade, F. N. (2011). Staffing patterns of state colleges of education libraries in Nigeria. Library Philosophy and Practice Journal, 1(4), 23-29.

UNESCO-UNEVOC. (2019). UNEVOC TVET leadership programme. UNESCO-UNEVOC global learning forum on advancing learning and innovation in TVET held the on 2nd-3rd December 2019 in Bonn, Germany. Retrieved from: http://www.unevoc unesco.org.

UNESCO. (2005). Suggestions for TVET and ESD action planning to UNESCO. Bonn, Germany: Final Report of the International Experts Meeting.

United Nations Development Programme. (2015). Sustainable development goals (SDGs): Post 2015 development agenda. Organized by the Government of Brazil and UNDP between 3rd and 5th December, 2015. Retrieved from: www.undp.en/home/s. 